\title{
Stabilization/Solidification of Tailings on Traditional Gold Mining in Kulon Progo Using Fly Ash
}

\author{
Ranno Marlany Rachman ${ }^{1 *}$, Ayi Syaeful Bahri', Yulinah Trihadiningrum \\ 1 Department of Environmental Engineering, Institut Teknologi Sepuluh Nopember, Surabaya 60111, Indonesia \\ * Corresponding author's e-mail: ranno_2004@yahoo.com
}

\begin{abstract}
Traditional gold mining activity is one of the sources of mercury contamination. Total mercury concentration in tailing ponds in Kulon Progo ranged from $164.49 \mathrm{mg} / \mathrm{kg}$ to $383.21 \mathrm{mg} / \mathrm{kg}$, which exceeded the quality standard values set by the government of Indonesia No. 101 of 2014, which is $75 \mathrm{mg} / \mathrm{kg}$. One method that can be applied is stabilization/solidification $(\mathrm{S} / \mathrm{S})$. This study aims to determine the optimum composition of the tailing mixture with fly ash in S/S process. The variations of fly ash composition with tailing are 100:0, 90:10, 80:20, 70:30, 60:40, 50:50, 40:60, 30:70, 20:80 and 10:90. The results of the study found that the optimum composition of fly ash: tailings was 10:90, with compression test of $74 \mathrm{ton} / \mathrm{m}^{2}$ and TCLP test was $0.0069 \mathrm{mg} / \mathrm{L}$. The obtained compression test results were in accordance with US EPA Standard quality of $35 \mathrm{ton} / \mathrm{m}^{2}$. TCLP test results meet the standard of Indonesian Government Regulation no. 101 of 2014, amounting to $0.05 \mathrm{mg} / \mathrm{L}$.
\end{abstract}

Keywords: mercury, fly ash, stabilization/solidification, tailings.

\section{INTRODUCTION}

Traditional gold mining in Kulon Progo has been operating for 15 years (Setiabudi, 2010). The traditional gold mining activity in Kulon Progo Yogyakarta, Indonesia is operated conventionally in an open location by using the amalgamation technique that involves mixing soil, water and mercury to form amalgam (alloy) used as gold binder (Rianto, 2010). Tailings constitute a waste generated from the mineral processing carried out with amalgamation technique (Lottermoser, 2010). The tailings from mining activities dumped around the mine without further processing, can causes contamination of the soil and river with mercury (Telmer and Stapper, 2012). According to Ogola et al. (2002), besides Hg there are several heavy metals contained in the tailings from the amalgamation process, such as $\mathrm{As}, \mathrm{Pb}, \mathrm{Cd}, \mathrm{Cr}$ and $\mathrm{Ni}$ but the result is still below the specified environmental standard, so it can be ignored. Mercury is the most dominant heavy metal due to its excessive use in gold extraction (Fashola et al., 2016). Mercury is identified as an element that has the quality of high toxicity and can be easily transformed into a more toxic form (Jaishankar, et al. 2014). Mercury would be very dangerous for human life if it entered through the food chain (Parsa et al., 2014). Mercury in the soil is absorbed by plants and it experiences a process of bio-magnification (Raymond et al., 2011). Mercury is one of the heavy metals contaminating the soil, which can be removed through remediation with either biological, chemical, or physical methods (Khalid et al., 2016).

According to Government Regulation no. 101 of 2014 on the Management of Hazardous and Toxic Wastes, the tailings from mineral processes fall into category 2 . The resulting tailings shall be kept in accordance with the Decision of the Head of the Environmental Impact Management Agency No. 1 of 1995 on Technical Procedures and Technical Requirements for the Storage and Collection of Hazardous and Dangerous Wastes.

One of remediation techniques that can be applied is stabilization/solidification (S/S) (Ganjidoust, et al. 2009). The purpose of the $\mathrm{S} / \mathrm{S}$ technique is to reduce the mobility of toxic contami- 
nants by increasing $\mathrm{pH}$, binding contaminants in a solid matrix, as well as improving the physical properties of the contaminant, compressive strength, permeability and durability. Hazardous waste treatment with S/S technology has the advantage of being cheap, environmentally friendly, and easy to apply (Chang, et al., 2008). In S/S technology, the waste is converted into solid compounds, thereby reducing the rate of contaminants (Yang and Min, 2008). The S/S technique requires an additional binder to physically and chemically encapsulate contaminants to form a more stable formation (Antemir et al., 2010). Some additive materials that can be used in $\mathrm{S} / \mathrm{S}$ process include portland cement, fly ash, lime, clay, zeolite (Weitzman, 1990).

Fly ash is a by-product of coal combustion in power plants (Canpolat F, 2011). It constitutes an additional material in the manufacture of cement. Fly ash has the advantage of being smooth and containing silica oxide which will react chemically with calcium hydroxide formed from the cement hydration process and produce a binding agent (Longarini, 2014). Fly ash has a small size, making the specimen denser because the cavity between aggregate granules is filled by fly ash (Nawaz, 2013). Fly Ash can minimize the pores of the specimen and utilize the pozzolanic character of fly ash to improve the quality of the specimen. Fly ash can improve the quality of the test specimen, making it more economical and water-resistant, enhancing the corrosive resistance (Ondova, 2013).

This study will test the ability of S/S technology to stabilize mercury contained in the tailings by using a mixture of fly ash. The characteristics of tailings should be known, to be considered for performing $\mathrm{S} / \mathrm{S}$. In $\mathrm{S} / \mathrm{S}$ techniques, variations of fly ash composition and tailings will affect the product quality. The optimum composition of fly ash and tailings should be considered for obtaining the desired $\mathrm{S} / \mathrm{S}$ product, with the least amount of additional fly ash.

\section{MATERIALS AND METHODS}

\section{Materials}

The fly ash supplied from PT Semen Indonesia was used throughout this research. Tailings were taken at the Kulon Progo gold mine site from 5 specified locations. Sampling was done using a core sampler which refers to US EPA. The tailing samples were collected from five locations with variation of depths equalling $30 \mathrm{~cm}, 60 \mathrm{~cm}$ and $90 \mathrm{~cm}$ for each location. The control ground was collected at $30 \mathrm{~cm}, 60 \mathrm{~cm}$ and $90 \mathrm{~cm}$ depth from two locations, then mixed and a single composite sample was obtained. Each sample was inserted into PET (Poly Ethylene Terephthalate) plastic and labelled, then inserted into an ice box at temperature of $4^{\circ} \mathrm{C}$ and brought to the laboratory for analysis of total mercury concentrations and tailing characteristics. The results of the five samples sites are composited into one sample based on the depth. The tailings sample locations can be seen in Figure 1.

\section{Test of mercury and tailings characteristics}

All samples were analyzed by soil physical characterization, based on particle size distribution analysis referring to ASTM D422. The test for chemical characteristics i.e. the water content test, was conducted with a gravimetric method and the $\mathrm{pH}$ measured by a $\mathrm{pH}$-meter. Particle size analysis methods and chemical characteristics of soil samples were applied and performed at the Soil Mechanics Laboratory and Stone in Civil Engineering FTSP ITS. The mercury levels were analyzed at LPPT UGM Yogyakarta by using Mercury Analyzer Type VM-3000. All samples were analyzed twice.

\section{Manufacturing of test material}

The test object was made by creating a cuboid mold specimen, $5 \mathrm{~cm}$ on each side. Variations in the composition of the specimen between fly ash and tailings were $100: 0 ; 90: 10 ; 80: 20 ; 30: 70$; $60: 40 ; 50: 50 ; 40: 60 ; 30: 70 ; 20: 80$ and 10:90. The procedure of stirring, preparing the specimen, compacting and treating the specimens referred to SNI 2493: 2011. The determination of the water requirement for the manufacture of the specimen was performed by a normal consistency test using a Vicat tool. Cement, tailings and water were mixed until homogeneous and made using a specimen mold.

\section{Mortar treatment (curing)}

The mortar treatment was done by keeping the mortar moist to prevent cracks in the test objects. The mortar was placed at room temperature for 28 days. In this study, moisture curing was performed by placing the test objects around a bucket of water and sealed using a large tub. 


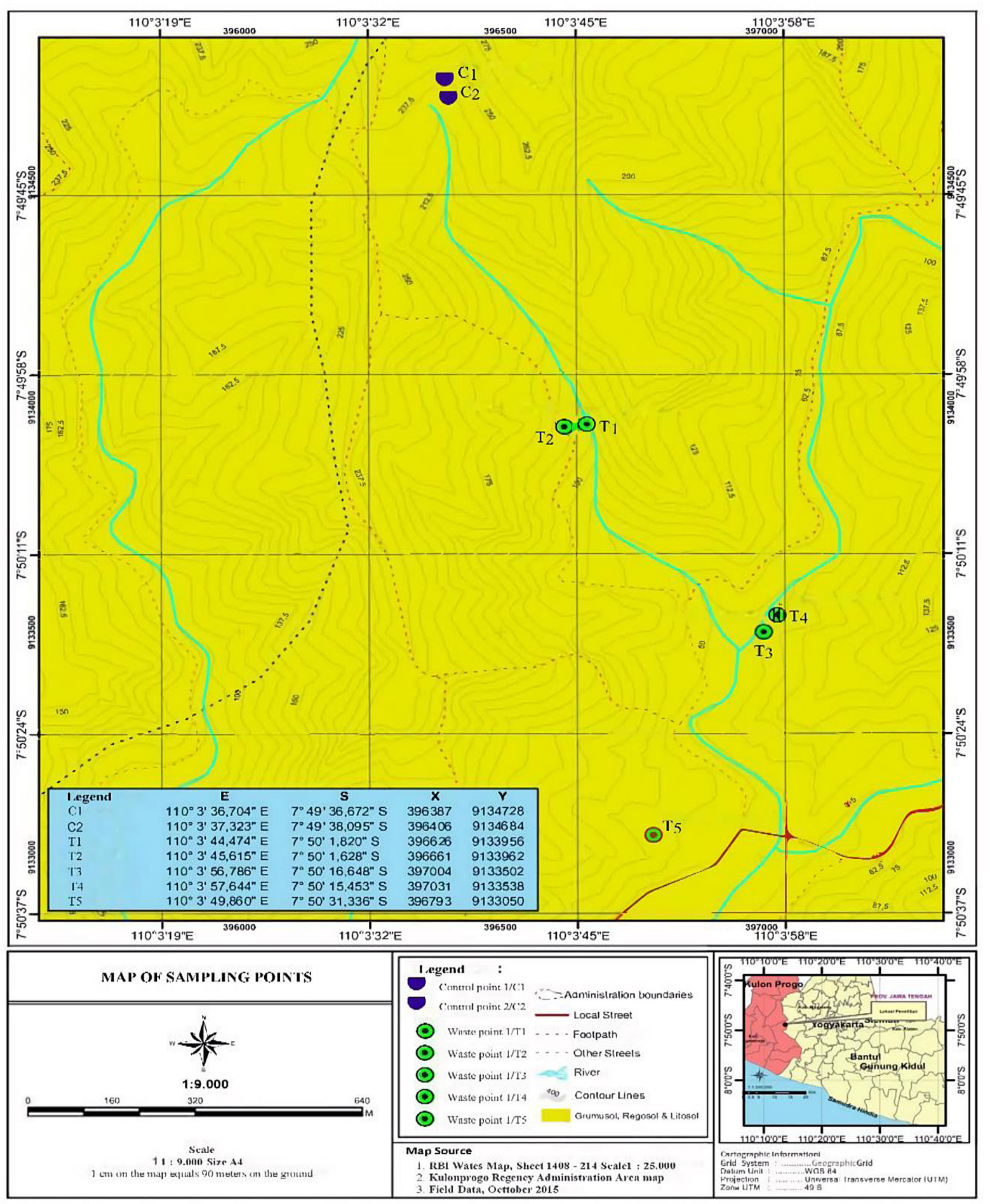

Figure 1. Map of soil sampling location

The treatment aimed to minimize the leaching of heavy metals contained in fly ash: tailing mortar.

\section{Compressive strength test}

The compressive strength test was performed by using the ASTM C109-93 test method. The compressive strength test was performed on a mortar that was subjected to the curing process for 28 days. The compressive strengths of specimens were measured using the Toorse Universal Testing Machine. The compressive strength test was performed to determine the maximum load that can be received by the specimen. The quality standard of compressive strength is $10 \mathrm{ton} / \mathrm{m}^{2}$ based on the Decree of Head of the Indonesia Environmental Impact Management Agency (Kepka Bapedal) No. 3 of 1995. 


\section{TCLP TEST}

TCLP test was conducted to determine the level of toxicity concentration contained in the waste. The quality standard of TCLP was according to PP No.101 Year 2014 is $0,05 \mathrm{mg} / \mathrm{L}$. The method used for the TCLP test was in accordance with US EPA method 1311.

The analysis included the discussion pertaining to the relationship between water requirements, compressive strength values and TCLP test results on the composition between fly ash and tailings. The optimum composition is determined by looking at the quality standards of each test with comparison of least fly ash usage.

\section{RESULTS AND DISCUSSION}

\section{Characteristics of soil samples}

The soil samples of the mine site in the district Kalirejo, Kulon Progo, Indonesia were physically yellowish brown in colour, containing sand, silt and clay. The physical and chemical characterization of control soil and tailings, are shown in Table 1 and Table 2.

On the basis of table 3 , the $\mathrm{pH}$ in tailings samples varied from 7.48 to $8.56 \mathrm{pH}$, while $\mathrm{pH}$ on control soil is 6.74 . Total mercury in the control soil sample was $0.079 \mathrm{mg} / \mathrm{kg}$. However, the re- sults of total mercury concentrations in tailings are much larger than control. Total mercury concentrations in tailings ranged between $164.19 \mathrm{mg} / \mathrm{kg}$ to $383.21 \mathrm{mg} / \mathrm{kg}$, which exceeds the quality standard set by the Indonesian government, amounting to $0.3 \mathrm{mg} / \mathrm{kg}$. The compressive strength test was performed on each variation of the mixtures between fly ash and the tailings formed in a mold (in duplicate) on each specimen. The value of compressive strength is presented in Table 4

\section{Compressive strength test}

In Table 4, it can be seen that all specimens met the minimum required compressive strengths with values varying from 74 ton $/ \mathrm{m}^{2}$ to 828 ton/ $\mathrm{m}^{2}$. The highest compressive strength value was obtained in the 80:20 composition, and the lowest in the 10:90 composition. According to Chindaprasirt et al. (2004), mechanically, the finer grain size of fly ash will increase the density of the specimen. The table shows the increasing number of fly ash additions in the sample will increase the compressive strength test. There is the possibility to obtain granules from fly ash and phosphogypsum with adequate strength for dustfree transportation, storage and dosage (Borowski and Hycnar, 2016). The compressive strength test results, the compressive strength of the mixtures increased along with the cement/fly ash ratio and curing time (Tang et al., 2016).

Table 1. Analysis Result of distribution grain of control soil

\begin{tabular}{|l|c|c|c|}
\hline \multicolumn{1}{|c|}{ Type of grain } & Particle size $(\mathrm{mm})$ & Content $(\%)$ & Water content (\%) \\
\hline Sand: & \multicolumn{2}{|c|}{} \\
\cline { 1 - 2 } - rough & $\geq 2.00$ & 39.36 & \\
\hline • medium & $\geq 0.425$ & & \multirow{2}{*}{19.16} \\
\hline - fine & $\geq 0.075$ & 34.46 & \\
\hline Silt & $\geq 0.0055$ & 24.61 & \\
\hline Clay & $\geq 0.0001$ & 1.57 & \\
\hline Gravel & $\geq 4.76$ & & \\
\hline
\end{tabular}

Table 2. Physical characterization of tailings

\begin{tabular}{|c|c|c|c|}
\hline Soil fraction & Particle size $(\mathrm{mm})$ & Content (\%) & Water content (\%) \\
\hline Gravel & $\geq 4.76$ & 1.86 & \multirow{7}{*}{13.24} \\
\hline \multicolumn{2}{|l|}{ Sand: } & \multirow{4}{*}{55.17} & \\
\hline - rough & $\geq 2.00$ & & \\
\hline - medium & $\geq 0.425$ & & \\
\hline - fine & $\geq 0.075$ & & \\
\hline Silt & $\geq 0.0055$ & 30.69 & \\
\hline Clay & $\geq 0.0001$ & 12.27 & \\
\hline
\end{tabular}


Table 3. The test result of total mercury concentration in tailing

\begin{tabular}{|c|c|c|c|}
\hline Sample code & Latitude/longitude & $\mathrm{pH}$ & $\begin{array}{c}\text { Total mercury concentration } \\
\text { in tailing }(\mathrm{mg} / \mathrm{kg})\end{array}$ \\
\hline C-1 & $\begin{array}{l}110^{\circ} 3^{\prime} 36,704 " \mathrm{E} \\
7^{\circ} 49^{\prime} 36,672 \text { " S }\end{array}$ & 6.74 & 0.079 \\
\hline$T-1$ & $\begin{array}{c}110^{\circ} 3^{\prime} 44,474 " \mathrm{E} \\
7^{\circ} 50^{\prime} 1,820^{\prime \prime} \mathrm{S}\end{array}$ & 8.56 & 352. 32 \\
\hline$T-I I$ & $\begin{array}{c}110^{\circ} 3^{\prime} 45,615^{\prime \prime} \mathrm{E} \\
7^{\circ} 50^{\prime} 1,628^{\prime \prime} \mathrm{S}\end{array}$ & 7.76 & 326.66 \\
\hline$T-I I I$ & $\begin{array}{l}110^{\circ} 3^{\prime} 56,786^{\prime \prime} \mathrm{E} \\
7^{\circ} 50^{\prime} 16,648 \text { ' S }\end{array}$ & 7.88 & 164.19 \\
\hline $\mathrm{T}-\mathrm{IV}$ & $\begin{array}{l}110^{\circ} 3^{\prime} 57,644^{\prime \prime} \mathrm{E} \\
7^{\circ} 50^{\prime} 15,453^{\prime \prime} \mathrm{S}\end{array}$ & 8.18 & 251.51 \\
\hline $\mathrm{T}-\mathrm{V}$ & $\begin{array}{l}110^{\circ} 3^{\prime} 49,860^{\prime \prime} \mathrm{E} \\
7^{\circ} 50^{\prime} 31,336^{\prime \prime} \mathrm{S}\end{array}$ & 7.48 & 383.21 \\
\hline
\end{tabular}

Table 4. Value of compressive strength

\begin{tabular}{|c|c|c|c|}
\hline $\begin{array}{c}\text { Composition } \\
\text { fly ash : tailings }\end{array}$ & $\begin{array}{c}\left.\text { Compressive strength (ton } / \mathrm{m}^{2}\right) \\
\text { Objects 1 }\end{array}$ & $\begin{array}{c}\text { Compressive strength }\left(\text { ton } / \mathrm{m}^{2}\right) \\
\text { Objects 2 }\end{array}$ & Average value (ton $\left./ \mathrm{m}^{2}\right)$ \\
\hline $100: 0$ & 764.79 & 890.34 & 828 \\
\hline $90: 10$ & 634.77 & 692.13 & 663 \\
\hline $80: 20$ & 894.16 & 834.89 & 865 \\
\hline $70: 30$ & 822.78 & 598.45 & 711 \\
\hline $60: 40$ & 664.73 & 356.26 & 510 \\
\hline $50: 50$ & 544.91 & 405.98 & 475 \\
\hline $40: 60$ & 225.61 & 212.87 & 219 \\
\hline $30: 70$ & 129.38 & 149.77 & 140 \\
\hline $20: 80$ & 73.29 & 94.96 & 84 \\
\hline $10: 90$ & 68.83 & 79.03 & 74 \\
\hline
\end{tabular}

\section{TCLP Test}

Prior to TCLP testing, sample preparation should be performed according to US EPA Method 1311. TCLP preparation included $\mathrm{pH}$ checking and determining the extraction fluid used. Two extraction liquids were applied, namely extraction fluid 1 and extraction fluid 2. Extraction fluid 1 was used if the $\mathrm{pH}$ sample was $<5$, and the extraction fluid 2 was used if the $\mathrm{pH}$ sample was $>5$ after addition of $3.5 \mathrm{~mL}$ of $\mathrm{HCl} 1 \mathrm{~N}$. The extraction fluid 1 comprised a mixture of a $1 \mathrm{~N}$ $\mathrm{NaOH}$ solution, glacial acetic acid, and aquades with a mixed $\mathrm{pH}$ of $4.93 \pm 0.05$. The extraction fluid 2 comprised a mixture of glacial acetic acid solution and aquades with a $\mathrm{pH}$ of $2.88 \pm 0.05$. The samples that had been mixed with the extraction solution agitated with a rotary agitator for $18 \pm 2$ hours at a speed of $30 \pm 2 \mathrm{rpm}$. The filter was filtered using Whatman filter paper type GF/F $47 \mathrm{~mm}$ with a pore size of $0.7 \mu \mathrm{m}$.

Mercury TCLP testing was performed using Mercury Analyzer Type VM-3000. The mercury TCLP test resulted in both sample variations can be seen in Table 5 .
The mercury TCLP tests resulted in all samples meeting the TCLP-B quality standard in government Regulations (PP) No. 101 of 2014, which is equal to $0.05 \mathrm{mg} / \mathrm{L}$. The TCLP value met the quality standard with a much lower value. The results obtained from all samples had a value from $0.0008 \mathrm{mg} / \mathrm{L}$ to $0.0069 \mathrm{mg} / \mathrm{L}$.

Precipitation is the reaction that binds $\mathrm{Hg}$ in the S/S process (LaGrega et al., 1994). Reactions that occur can be seen as follows

$$
\begin{gathered}
\mathrm{Hg}^{2+}+2\left(\mathrm{OH}^{-}\right) \rightarrow \mathrm{Hg}(\mathrm{OH})_{2} \downarrow \\
\mathrm{Hg}(\mathrm{OH})_{2} \rightarrow \mathrm{HgO} \downarrow+\mathrm{H}_{2} \mathrm{O} \\
\mathrm{Hg}^{2+}+\mathrm{CO}_{3}^{2-} \rightarrow \mathrm{HgCO}_{3} \downarrow
\end{gathered}
$$

The S/S test specimens were extracted on TCLP test using $\mathrm{CH}_{3} \mathrm{COOH}$ to determine the presence of $\mathrm{Hg}$ which may be soluble in acid. The $\mathrm{Hg}$ precipitation reaction can be written as follows:

$$
\mathrm{HgO} \downarrow+2 \mathrm{CH}_{3} \mathrm{COOH} \rightarrow \mathrm{Hg}\left(\mathrm{CH}_{3} \mathrm{COO}\right)_{2}+\mathrm{H}_{2} \mathrm{O}
$$

The reaction occurs on silica, aluminate, and calcium pozzolan. According to Hagemann (2009), the material will survive under $\mathrm{pH} 4-12$ conditions at TCLP. The solubility of silica and 
Table 5. TCLP Test Results

\begin{tabular}{|c|c|}
\hline $\begin{array}{c}\text { Composition } \\
\text { fly ash : tailings }\end{array}$ & Hg concentration (mg/L) \\
\hline $100: 0$ & 0.0008 \\
\hline $90: 10$ & 0.0007 \\
\hline $80: 20$ & 0.0039 \\
\hline $70: 30$ & 0.0018 \\
\hline $60: 40$ & 0.0023 \\
\hline $50: 50$ & 0.0015 \\
\hline $40: 60$ & 0.0016 \\
\hline $30: 70$ & 0.0014 \\
\hline $20: 80$ & 0.0019 \\
\hline $10: 90$ & 0.0069 \\
\hline
\end{tabular}

alum present in fly ash and clay may increase the $\mathrm{pH}$ so that it can react by forming a cement hydration reaction. The $\mathrm{pH}$ has a great influence on the spread of metal activity. At acidic $\mathrm{pH}$, heavy metal concentrations are more easily dissolved in the soil. The acidic conditions also easily corrode the test object, decreasing its quality. This is due to the heavy metal properties that are resistant to neutral or alkaline conditions. Under acidic conditions, heavy metals in the soil are also easier to react with other elements present in the soil.

According to Sanemasa (1975), elemental mercury is insoluble in alkaline or neutral solutions. Meanwhile, according to Riogilang and Masloman (2009), the tailings from gold mining generally contain inert minerals such as quartz, calcite, and various aluminosilicates. These minerals play a role in this $\mathrm{S} / \mathrm{S}$ process. The quality of the $\mathrm{S} / \mathrm{S}$ product improves because of the addition of mineral content contained in the tailings. The fly ash material already contains high silica and aluminate, whichcan optimize the $\mathrm{S} / \mathrm{S}$ process.

\section{CONCLUSION}

In this work, the soil texture triangle of the total content of each type of grain, tailings are included in the category of sandy loam. Initial mercury tailings exceeded the quality standard of Government Regulations (PP) No. 101 of 2014, amounting to $75 \mathrm{mg} / \mathrm{kg}$, in which the active tailings contained mercury with a total concentration between 164.19 until $383.21 \mathrm{mg} / \mathrm{kg}$, with $\mathrm{pH}$ ranging from 7.48 to 8.56 . The S/S method using fly ash on a mercury contaminated tailings was capable of meeting the required minimum compressive strength value and the required TCLP value. All composition variations of tailings had a higher compressive strength value than the quality standard with a minimum compressive strength value of 74 ton $/ \mathrm{m}^{2}$ in the composition containing $10 \%$ fly ash and $90 \%$ tailings. The TCLP value was much lower than the quality standard value $<0.05 \mathrm{mg} / \mathrm{L}$.

On the basis of the TCLP results, the stabilized materials meet the established quality standards. The products of S/S in Indonesia even meet the environmental quality standard of Head of BAPEDAL No. 04 of 1995 which was collected at a place of hazardous and toxic waste. The material obtained from $\mathrm{S} / \mathrm{S}$ needs further study and so that new regulations may be developed.

\section{Acknowledgements}

The authors would like to thank LPDP (Indonesia Endowment Fund for Education) for financial support of this research.

\section{REFERENCES}

1. Antemir A., Hills C.D., Careya P.J., Magnieb M.C., Polettini A. 2010. Investigation of 4 years old stablised/solidified and accelerated carbonated contaminated soil. Journal of Hazardous Materials, 181, 543-555.

2. Borowski G., Hycnar J.J. 2016. The effect of granulated fly ashes with phosphogypsum on the hardening of cement mortar. Technical Transactions Civil Engineering, 2, 37-45.

3. Canpolat F. 2011. The role of coal combustion products in sustainable construction metals. The Indian Concrete Journal, 1, 26-38.

4. Chang J.E., Lin T.T., Ko M.S., Liaw D.S. 1999. Stabilization/solidification of sludge's containing heavy metals by using cement and waste pozzolans. Journal of Environmental Science and Health, 5, 1143-1160.

5. Chindaprasirt P., Jaturapitakkul C., Sinsiri T. 2004. Effect of fly ash fineness on compressive strength and pore size of blended cement paste. Cement \& Concrete Composites, 27, 425-428.

6. Decree of the Head of Environmental Impact Management Agency no. 03 of 1995 on Technical Requirements for Processing Hazardous Wastes of Hazardous Materials. Environmental impact Control Agency.

7. Fashola M.O., Jeme V.M.N., Babalola O.O. 2016. Heavy metal pollution from gold mines: environmental effects and bacterial strategies for resistance. International Journal of Environmental Research and Public Health, 13(11), 1047. 
8. Ganjidoust H., Hassani A., Ashkiki A.B. 2009. Cement based solidification/stabilization of heavy metal contaminated soils with the objective of achieving high compressive strength for the final matrix. Scientia Iranica, 2, 107-115.

9. Government Regulation of the Republic of Indonesia No. 101 Year 2014 on the Management of Hazardous and Toxic Waste.

10. Hagermann S. 2009. Technologies for the stabilization of elemental mercury and mercury-contaminant waste. Final Report Gesellschaft für Anlagenund Reaktorsicherheit (GRS).

11. Jaishankar M., Tseten T., Anbalagan N., Mathew B.B., Beeregowda K.N. 2014. Toxicity, mechanism and health effects of some heavy metals. Interdisciplinary Toxicology, 7(2), 60-72.

12. Khalid S., Shahid M., Niazi N.K., Murtaza B., Bibi I., Dumat C. 2016. Journal of Geochemical Exploration, 182, 247-268.

13. LaGrega M.D., Buckingham P.I., Evans J.C. 1994. Hazardous Waste Management. McGraw-Hill, Inc., Singapore.

14. Longarini N., Crespi P.G., Zucca M., Giordano N., Silvestro G. 2014. The advantages of fly ash use in concrete structures. Journal of the Polish Mineral Engineering Society, 1, 141-145.

15. Lottermoser B.G. Mine Wastes Characterization, Treatment and Environmental Impacts, 3rd ed. London, 2010.

16. Nawaz. 2013. disposal and utilization of fly ash to protect the environment. international journal of innovative research in science, Engineering and Technology, 2, 5259-5266.

17. Ogola J.S., Mitullah W.V., Omulo M.A. 2002. Impact of gold mining on the environment and human health a case study in the Migori Gold Belt Kenya. Environmental Research, 107, 89-97.

18. Ondova M., Stevulova N., Meciarova L. 2013. The potential of higher share of fly ash as cement replacement in the concrete pavement. Procedia Engineering, 65, 45-50.

19. Parsa Y., Nabavi S.M.B., Nabavi S.N., Hosseini M. 2014. Mercury accumulation in food chain of fish, $\mathrm{crab}$ and sea bird from Arvand River. J Marine Sci Res Dev, 4, 148.

20. Rachman R.M., Karisma E.D., Trihadiningrum Y.
2017. Stabilization/solidification of mercury contaminated soil of traditional gold mining in Kulon Progo Yogyakarta, Indonesia using a mixture of portland cement and tras soil. ARPN Journal of Engineering and Applied Sciences, 12, 6380-6387.

21. Wuana R., Okieimen F.E. 2011. Heavy metals in contaminated soils: a review of sources. Chemistry, risks and best available strategies for remediation. ISRN Ecology, 402647, pp. 20.

22. Rianto S. 2010. Analysis factors associated with mercury poisoning in traditional gold miners in Jendi Village Kecamatan Selogiri, Wonogiri regency. Master of Health. Thesis Environment Diponogoro University. Semarang.

23. Riogilang H., Masloman H. 2009. Utilization of mining waste for material building construction. Ekoton, 9(1), 69-73.

24. Sanemasa I. 1975. The solubility of elemental mercury vapor in water. Bulletin of the Chemical Society of Japan, 46, 1795-1798.

25. Setiabudi B.T. 2005. Distribution of mercury due to gold mining business in Sangon Region Kulon Progo Regency Di Yogyakarta. Colloquium Field Results.

26. Tang Q., Liu Y., Fan Gu F., Zhou T. 2016. Solidification/stabilization of fly ash from a municipal solid waste incineration facility using portland cement. Advances in Materials Science and Engineering, 1, 1-10.

27. Telmer K., Stapper D.A. 2012. Practical Guide: reducing mercury use in artisanal and small scale gold mining. united nations environment program. Nairobi Kenya: Geneva, Switzerland.

28. US EPA. 2001. Methods for collection. storage and manipulation of sediments for chemical and toxicological analyses technical manual. U.S. Environmental Protection Agency, Washington.

29. US EPA. 1992. Toxicity Characteristic Leaching Procedure. U.S. Environmental Protection Agency, Washington.

30. Weitzman L. 1990. Factor for selecting appropriate solidification/stabilization methods. Journal of Hazardous Materials, 24, 157-168.

31. Yang YC., Min G.B. 2008. Solidification/stabilization of soil contaminated with metal. Review Journal The Institution of Engineers. Malaysia, 69, 3-10. 